\title{
"África em Portugal": devoções, irmandades e escravidão no Reino de Portugal, século XVIII
}

\author{
Lucilene REGINALDO ${ }^{\bullet}$
}

\begin{abstract}
Resumo: Este artigo discute a história das irmandades que congregaram escravos e libertos africanos e seus descendentes em Portugal, no século XVIII. Para tanto, leva em consideração um panorama mais geral da história e da historiografia da escravidão e da presença africana em Portugal. Busca compreender o contexto de surgimento e as singularidades das irmandades de negros no cenário das confrarias leigas portuguesas. E, finalmente, destaca com especial atenção, a importância destas organizações na configuração da vida comunitária e na defesa dos interesses das populações liberta e escrava.
\end{abstract}

Palavras-chave: Escravidão; Irmandades; Africanos; Portugal.

Falta a Manoel Rodrigues da Silva Pereira, morador na Rua da Atalaya ao Bairro Alto, quase no meio da sobredita, um preto de nome Francisco José, de idade, pouco mais ou menos, vinte e dois anos, os sinaes pessoais são os seguintes: é bem feito, alto, grosso, bons olhos, com semblante alegre, a orelha furada com um brinco de topázio amarelo; de cabeleira redonda.

Hebdomadário Lisbonense, n.o. 19, 8 de novembro de 1766.

Um anúncio de fuga de escravos num periódico oitocentista carioca, baiano ou pernambucano, muito provavelmente, não provocará nenhum estranhamento nos leitores brasileiros, estudiosos profissionais ou investigadores diletantes da história nacional. No entanto, pode causar surpresa, mesmo no seleto grupo destacado, um anúncio desta natureza num periódico

- Departamento de Ciências Humanas e Filosofia - Universidade Estadual de Feira de Santana - 44031-460 - Feira de Santana - BA Brasil. E-mail: lureginaldo@gmail.com

HISTÓRIA, São Paulo, 28 (1): 2009 
lisboeta setecentista, a exemplo deste que transcrevemos acima. Verdade é que desconhecemos, quase por completo, a história dos africanos e seus descendentes em Portugal. Mas que isso não seja motivo de constrangimento para os brasileiros, pois a própria historiografia portuguesa tem dado passos tímidos e temerosos nesta direção. Segundo Silvia Lara, em Portugal:

o tema tem se desenvolvido quase na surdina, intrinsecamente ligado aos debates que cercam a própria história do Império Português. Com efeito, o significado político da escravidão em Portugal e nas "colônias" parece conter um potencial explosivo. (LARA, 2001:307-404).

Durante o regime salazarista, investigações que ousaram questionar a "vocação luso-tropicalista" do império português foram reprimidas. Num contexto de embates políticos e ideológicos pela manutenção do regime colonial em África, e posterior eclosão das guerras anticoloniais o tema da escravatura ameaçava abalar os pilares ideológicos do colonialismo. (CASTRO HERIQUES, 1997:29). Embora a historiografia portuguesa na atualidade tenha conseguido se libertar dos grilhões do fascismo, os silêncios sobre a escravidão no Reino, assim como um certo viés "colonialista" na abordagem da história africana, deixam entrever feridas não muito bem cicatrizadas ${ }^{1}$.

Para finalizar este preâmbulo, algumas palavras de esclarecimento sobre o título deste artigo. Portugal em África foi título de um periódico publicado entre os anos de 1894-1973, cujo objetivo era divulgar estudos sobre a presença e protagonismo dos portugueses nas suas colônias africanas. Os limites cronológicos da publicação denunciam seu comprometimento com a política colonial portuguesa. O título deste artigo parafraseia e inverte a equação, chamando a atenção para a presença e protagonismo dos africanos e seus descendentes "no coração do Império", tomando de empréstimo o belo título de Didier Lahon (LAHON, 1999A). 
“ÁFRICA EM PORTUGAL"...

\section{Os africanos em Portugal: de conversos a escravos}

Nos primeiros séculos de contatos, inúmeros africanos foram levados a Portugal para serem instruídos na fé, na cultura e nas línguas ocidentais. Alguns desembarcaram em Lisboa como homens livres, eram representantes da corte do Mani Congo, embaixadores, parentes da família real. Destes, alguns poucos se tornaram intérpretes (então chamados "línguas"), catequistas e sacerdotes. Um médico alemão que visitou Portugal em 1494

declarou ter visto muitos mancebos negros que tinham sido, ou estavam a ser, educados em Latim e Teologia, com o objetivo de os fazer regressar à ilha de S. Tomé, ao reino do Congo ou qualquer outro lugar, como missionários, interpretes e emissários de D. João II. (BOXER, 1989: 14-15).

A política de controle da expansão do catolicismo, levada a cabo pelos soberanos do Congo, investiu na formação de um clero africano. Mesmo após a morte de seu filho bispo, o célebre D. Henrique, o Mani Congo D. Afonso I continuou enviando a Lisboa jovens sobrinhos e primos para serem educados no Mosteiro de Santo Elói (BOXER, 1989:16). Por outro lado, o empenho dos soberanos e religiosos portugueses na formação de um clero indígena indica uma postura "mais cordata", tendo em vista o preconceito característico das relações dos europeus com africanos a partir do estabelecimento do comércio escravista em larga escala. Nesse sentido, as categorias de identificação utilizadas nos diferentes períodos revelam sistemas diversos de classificação, organização e, portanto, de percepção do africano.

Nos primeiros séculos de contato, os africanos foram primeiro identificados como gentios, ou seja, povos pagãos, seguidores da "lei natural" que viviam, portanto, no erro e na superstição ${ }^{2}$. No movimento de expansão do catolicismo, os gentios eram povos almejados pela catequese missionária (SOARES, 1998: 77,78). Vê-se então que, o proselitismo dos 
soberanos portugueses estava consonante com o projeto de expansão missionária. Entretanto, à medida que o comércio de escravos africanos fincava raízes no ocidente, a categoria gentio dava lugar a termos mais seculares e, portanto, mais apropriados aos novos interesses mercantis ${ }^{3}$.

Sem a mesma sorte daqueles destinados a serem educados na fé e na religião católica, se é que assim podemos dizer, no decorrer dos séculos XVI a XVIII, milhares de africanos chegaram a Portugal na condição de escravos. Desde 1512, Lisboa foi o único porto do reino onde era permitido o desembarque de cativos. No entanto, efetivamente, até pelo menos a proibição de 1761, Setúbal, Porto e muitas outras cidades portuárias localizadas na região do Algarve receberam grande número de escravos africanos (LAHON, 1999A:32).

"A importância que os portos algarvios, como Lagos, tiveram na importação de cativos fez da região uma das que, no conjunto do território português, contavam com maior percentagem de escravos na sua população" (FONSECA, 1996: 153). No século XVI, apesar do exclusivismo de Lisboa, em termos proporcionais, os números da população escrava no Algarve eram semelhantes aos da capital. Cerca de 6.000 escravos representavam algo em torno de $10 \%$ da população total da região. (LAHON 1999A: 13). Para o Alentejo, a partir de um significativo número de registros de batismo da cidade de Évora e principais vilas e termos rurais da região, Fonseca sugere um cálculo aproximado da população escrava. Segundo este autor, no período de 1588 a 1600, os escravos representaram $5,44 \%$ do total de batizados (FONSECA, 1997:15). Ao norte, a cidade do Porto possuía um movimentado mercado de escravos desde a segunda metade do século XV. Na década de 1540, os escravos chegaram a representar $6 \%$ dos batismos realizados na Sé Catedral (SAUNDERS, 1982: 83).

Lisboa, "não era só a maior das cidades, mas também a maior das concentrações de escravos em todo Reino". Um recenseamento das paróquias da cidade, realizado nos anos de 1551-52, permite concluir que Lisboa possuía uma população de 9.950 escravos, "isto é, 9,95\% ou digamos que $10 \%$ da população 
"ÁFRICA EM PORTUGAL"...

total da cidade". (SAUNDERS, 1982: 84). Em 1620, os escravos contavam 10.470 num total populacional de 143.000 (LAHON, 1999A:13).

"Por amor de Deus", as Misericórdias enterravam os pobres falecidos, incluindo neste rol os escravos e libertos negros (GUIMARÃES, 2001:116-17). Os livros de sepultamentos da Santa Casa de Misericórdia de Lisboa confirmam a presença significativa da população negra na cidade no decorrer do século XVIII. Em 1756, a Misericórdia fez o enterro de 1.235 pessoas, entre estes, $16,8 \%$ eram pessoas de cor. Na década de 1760, a população negra representa $15 \%$ dos defuntos enterrados pela Misericórdia, em alguns períodos chega a representar 17,8 \% "e sua participação nunca fica abaixo de 12,7\%, como o ocorrido no ano de 1765 (LAHON, 1999A: 50-1).

No final do século XVI, havia em Lisboa escravos africanos de várias procedências. Em sua Crônica da Companhia de Jesus em Portugal, o padre Baltazar Teles registra que, no ano de 1567, um padre mestre dos jesuítas em Lisboa organizou um esquema de revezamento para que os escravos pudessem assistir à doutrina pelo menos um domingo a cada mês. Segundo seu esquema:

cada Domingo sairiam à doutrina cinco nações, e como eram por todas vinte, as que então havia em Lisboa ficavam no mês caindo um Domingo para a doutrina e três domingos e os dias santos lhe ficavam livres para suas recreações. ${ }^{4}$

Esta grande variedade percebida pelos religiosos jesuítas tem uma explicação simples. As vias de abastecimento dos mercados ibéricos foram múltiplas e variáveis de acordo com cada época e conjuntura específica. O volume, bem como as vias de abastecimento do tráfico de escravos para Portugal e Península Ibérica, em geral são ainda pouco conhecidos. $\mathrm{Na}$ verdade, isto reflete um grande silêncio no que diz respeito ao tema da escravidão, tratado pela historiografia portuguesa "quase na surdina". O tráfico é apenas uma entre tantas outras interrogações uma vez que, como afirma Lara "infelizmente 
continuam sendo poucos os estudos empreendidos por portugueses sobre a experiência dos africanos e seus descendentes como cativos, libertos ou livres no reino português" (LARA, 2001:387-404).

De um modo geral, as origens geográficas e culturais dos cativos negros em Portugal eram semelhantes às dos escravos embarcados para as Américas. Nos séculos XV e XVI, "os escravos presentes em Lisboa, Algarve, Alentejo e Andaluzia, provinham principalmente de etnias que povoavam as regiões do atual Senegal até a atual Guiné-Bissau". Muitos destes cativos foram identificados na documentação como procedentes de Cabo Verde. Esta "falsa" identificação" decorria do fato de que muitos originários das margens dos rios da Guiné e Senegâmbia, antes de serem vendidos para a metrópole, permaneciam em Cabo Verde por um período mais ou menos longo (LAHON, 2001).

Embora a presença dos centro-africanos (congos e angolas) no contingente de cativos enviados para o Reino date do final do século $X V$, foi somente no final do século XVI e, principalmente, no início do XVII que esses africanos começaram a ser identificados com mais frequência na documentação. A partir de então, "as etnias que pertencem ao grupo lingüístico banto, constituem provavelmente, o maior contingente de escravos introduzidos em Portugal até 1761 " (LAHON, 1999A:38).

Nos séculos XVII e XVIII, era comum encontrar-se, entre a população cativa de Lisboa, escravos identificados como minas. Estes povos provenientes da Costa do Ouro, da Costa dos Escravos e do Golfo do Benin começaram a entrar em Portugal no período de intensificação do tráfico baiano com esta região africana (LAHON, 1999A: 71).

Trabalhadores escravos de origem africana eram presença marcante nas cidades e vilas mais importantes do reino português. Em Lisboa, os escravos eram responsáveis por variadas tarefas: eram criados, cozinheiros, ferreiros, serralheiros, alfaiates, aguadeiros, caiadores e marítimos; entre as mulheres, destacavam-se as vendedoras ambulantes de tremoços, mexilhões, favas, bolos e outras iguarias, além das 
lavadeiras, trapeiras, aguadeiras e calhandreiras, entre inúmeras outras atividades. À semelhança do que ocorria na América, igualmente "negra era a mão da limpeza". As negras de canastra, também chamadas calhandreiras, eram responsáveis por um serviço público importantíssimo. "Era o trabalho da remoção dos dejetos humanos (...) conduzindo-os em calhandras levadas sobre o ombro, ou equilibradas na cabeça, para despejo ao mar, na Ribeira" (TINHORÃO, 1997:114).

$\mathrm{Na}$ Lisboa setecentista, seguindo a tendência de todo o Reino, prevaleciam os pequenos proprietários. Um grande número de senhores e senhoras alugava os serviços de seus cativos. No ano de 1709, as "pretas que vendem milho, arroz e chicharros cozidos ao povo nas escadas do hospital do Rossio" apresentaram ao Rei uma petição. Elas reclamavam das perseguições, maus tratos e espancamentos que vinham sofrendo da parte do corregedor e do alcaide daquele bairro.

Sendo as suplicantes umas pobres pretas, que não tinham outro ofício mais que venderem ao povo aquele sustento naquele lugar das escadas do Rossio, pagando cada uma um cruzado, todos os anos, ao senado da câmara e nesta posse desde que o mundo era mundo, por si e suas antepassadas; por cuja razão recorriam todas ao pé de Vossa Majestade lhe acudisse e valesse na violência que lhes faziam os ditos alcaides, para que as deixasse vender no lugar das ditas escadas (...) sabido e certo lugar para o povo ir comprar o que as suplicantes vendiam, de cujo lucro pagavam a seus senhores para seu sustento, de seus maridos e filhos e forravam ainda para suas irmandades e liberdades $(\ldots)^{5}$

A maioria das negras que vendia nas escadas do Hospital do Rossio era do serviço de ganho. Elas reivindicavam o reconhecimento de sua atividade e local de trabalho com base no costume, uma vez que estavam nesta posse, segundo suas próprias palavras, "desde que o mundo era mundo" ${ }^{6}$. Algumas negras de ganho conseguiam economizar o bastante para comprar sua alforria, de seus filhos ou outros parentes próximos. Economizar e contribuir para suas irmandades também contava entre as prioridades destas mulheres, assim como de muitos 
outros escravos e libertos, como veremos mais detalhadamente nas próximas linhas.

\section{As irmandades e a defesa dos escravos e libertos negros em Portugal}

A primeira irmandade de negros de Lisboa nasceu na Igreja do Convento de São Domingos. Neste convento havia uma irmandade de N.S. do Rosário instituída por pessoas brancas, provavelmente no final do século XV, mas a partir do século XVI, paulatinamente, os negros foram ocupando espaço na instituição (BRÁSIO, 1944: 76). Em 1551, a Confraria do Rosário do Convento de São Domingos estava "repartida em duas, uma de pessoas honradas, e outra dos pretos forros e escravos de Lisboa"7. Uma série de conflitos entre "os irmãos pretos" e as "pessoas honradas" levou à cisão definitiva do grupo. Em 1565, os irmãos negros tiveram seu primeiro compromisso aprovado pela autoridade régia. Apesar disto, o acirramento das disputas, que chegou a envolver os superiores do convento e até o Papa, levou à expulsão da irmandade dos negros do templo dominicano no fim do século XVI (LAHON, 1999A: 61-62).

$\mathrm{Na}$ década de 1580, surgiram em Lisboa duas confrarias exclusivamente de negros: a de N. S. de Guadalupe, mais tarde denominada N. S. de Guadalupe e São Benedito, no convento de São Francisco, e uma outra, sob a invocação de Jesus Maria José, no Convento do Carmo. Nos séculos XVII e XVIII, Lisboa assistiu ao nascimento de mais irmandades de negros. No início do XVII foi criada a irmandade do Rosário dos Pretos no Convento do Salvador; e a partir daí, até meados do século XVIII, os negros em Portugal instituíram mais três confrarias: a do Rosário a Resgatada, no Convento da Trindade, N. S. do Rosário dos pretos, no Convento da Graça e, finalmente uma outra confraria sob a invocação de Jesus, Maria, José, esta agora no Convento de Jesus, dos religiosos franciscanos (LAHON, 1999B: 140-141). Ainda no século XVIII, foi criada a Confraria de Nossa 
Senhora do Rosário e dos Santos Reis Magos; teve vida efêmera, mas renasceu, sob a mesma invocação, na primeira metade do século XIX. O surgimento das confrarias de negros expressa o crescimento desta população em Portugal, e, sobretudo, a importância que este tipo de associação foi adquirindo entre os africanos e seus descendentes no Reino.

As irmandades de negros não estiveram restritas a Lisboa. Foram criadas em todas as localidades que concentraram populações de origem africana. Depois da de Lisboa, a irmandade do Rosário dos pretos de Évora é a mais antiga (BRÁSIO, 1944: 99). As primeiras notícias desta irmandade datam do início do século XVI. Em diversas outras localidades do Alentejo também foram criadas irmandades de negros: Alcácer do Sal, Setúbal, Vila Viçosa, Grândola, Montemor-oNovo, Estremoz e Elvas, só para registrar as mais antigas. No Algarve e ao norte do Tejo, as irmandades de negros também tiveram presença marcante (BRÁSIO, 1944: 102). No Porto, no decorrer do século XVIII, estavam em atividade pelo menos quatro irmandades: uma do Rosário e São Benedito, na igreja do Convento dos franciscanos na Freguesia de São Bartolomeu; uma outra, sob a invocação do Rosário dos pretos no convento dominicano da Freguesia da Sé; uma dedicada a São Gonçalo Garcia dos homens pardos, e uma quarta, também dedicada ao Rosário de Nossa Senhora, na igreja paroquial de Massarelos (LAHON, 1999B: 140-141).

A classificação de "cor", como quesito importante na organização das confrarias leigas, surgiu com o crescimento do número de africanos no Reino e sua entrada na cristandade. Até então, nas irmandades lusitanas, eram diversos os critérios de pertença. Podiam estar baseados na hierarquia do antigo regime, em vínculos corporativos ou de afinidade profissional, no gênero, ou ainda, na origem nacional (PENTEADO, 1995:30).

A festa do Corpo de Deus era um momento importantíssimo do ponto de vista cívico e religioso nos municípios portugueses. $\mathrm{Na}$ procissão desfilavam todas as irmandades formalmente constituídas, além da câmara e membros de diversos corpos militares. O desfile das 143 
irmandades que acompanharam a procissão do Corpo de Deus, em Lisboa, no ano de 1719, oferece uma pequena mostra da mencionada diversidade de critérios. Desfilaram, entre tantas outras, a Irmandade da Senhora da Saúde, "que se compõem de muita fidalguia da Corte"; a de São Miguel dos nobres, a de Nossa Senhora da Oliveira dos Sapateiros, a de São José dos Carpinteiros, a confraria de Santo André "que é da nação Flamenga" 8 . Não resta dúvidas de que as instituições portuguesas foram profundamente afetadas pela expansão ultramarina. Além de "descobrir" novos mundos, os portugueses levaram para dentro do pequeno reino gentes provenientes destes mundos. Nesta mesma procissão de 1719, desfilaram igualmente as irmandades de Jesus Maria José, do Convento do Carmo, Rosário do Convento da Trindade e São Benedito do Convento de São Francisco sendo "que todas as três eram de homens pretos". . A presença dos africanos no Reino deu início a um capítulo particular da história social portuguesa.

No final do século XVI, a população negra em Lisboa podia ser identificada de acordo com seus laços de procedência ou mais especificamente étnicos. Como já mencionei anteriormente, no ano de 1557, o padre mestre da Companhia de Jesus em Lisboa identificou as vinte principais nações de africanos em Lisboa $^{10}$. No entanto, deste total, nos registros do século XVIII, não restaram mais que três. O direcionamento do tráfico para regiões mais determinadas e a vigência de certa "normatização" escravista na identificação dos grupos explica, em grande parte, essa drástica redução. Alguns poucos registros indicam a importância destas identificações na organização das confrarias negras em Portugal.

No primeiro Domingo de outubro de 1730, os irmãos do Rosário do Convento do Salvador celebraram a festa de Nossa Senhora do Rosário. Era prática comum o convite a outras irmandades para participarem da festa do padroeiro. Para a animada festa de 1730, o Rei Angola, da Confraria do Salvador, mandou uma carta convite ao Rei Mina, da Confraria de N.S. de Guadalupe e São Benedito, do Convento dos franciscanos (LAHON, 2001: 501). A mesma irmandade do Convento do 
Salvador, ainda no século XVIII, costumava identificar-se como "Confraria de N. S. do Rosário dos Homens Pretos do Reinado do Congo" "11. A raridade de registros sobre as etnias ou procedência nas irmandades negras em Portugal faz pensar sobre a relevância desta marca de identidade nesta comunidade escrava em específico ${ }^{12}$.

A predominância do tráfico com a África Central, a partir do século XVII, levou a concentração de um grande número de africanos dessa origem em Lisboa e em outras partes do reino. As coroações de reis e rainhas do "do Congo e de Angola", preservadas dentro das irmandades, dão mostra do vigor deste grupo em termos numéricos e culturais ${ }^{13}$. No século XVIII, reis "congos e angolas" eram coroados nas irmandades do Porto, Braga e Vila Viçosa, além de Lisboa, é claro (LAHON, 1999A: 71). O Rei "mina" na irmandade de N.S. de Guadalupe e São Benedito também chama a atenção para a importância deste agrupamento na Lisboa setecentista. Lamentavelmente, a ausência de estudos sobre o tráfico de escravos para a Península Ibérica não permite avançar muito na discussão.

De todas as maneiras, é possível sugerir que, dada as particularidades da escravidão no reino, sobretudo no que diz respeito ao número e à concentração urbana dos cativos, a união em comunidades mais abertas tenha sido a estratégia construída pelo grupo. É bom lembrar que a identificação étnica é apenas uma das múltiplas identidades que o escravo e o liberto poderiam assumir no decorrer de suas vidas (LOVEJOY, 2002: 34).

No início do século XVIII, a população negra em Lisboa possuía pelo menos 9 confrarias exclusivas. Para responder à pergunta fundamental sobre a importância destas associações entre os escravos e libertos negros, cabe, primeiramente, compreender qual é sua particularidade em relação às confrarias em geral.

Em meados do século XVIII, as confrarias católicas estavam espalhadas por todo território português. Neste período, chegaram a congregar milhares de indivíduos. Ao investigar os motivos de adesão às confrarias católicas, 
Penteado concluiu que a busca de proteção divina, o auxílio nos momentos difíceis da vida, a garantia de um funeral cristão e a multiplicação dos tempos de sociabilidade eram os grandes fatores de motivação. Segundo o autor, as irmandades abriam uma possibilidade de exercício de poder para os grupos sociais menos privilegiados "aumentando assim seus níveis de protagonismo social". (PENTEADO, 1995: 28,30)

As irmandades de escravos e forros, à semelhança das irmandades de brancos, também cumpriam um papel religioso e de ajuda mútua. A importância e a forma do exercício de poder protagonizado pelas confrarias negras parecem ter sido o grande diferencial em relação às confrarias dos brancos. A conquista de alguns privilégios régios permitiu que as confrarias de negros em Portugal se tornassem "para seus irmãos escravos, um lugar de proteção e apoio jurídico, podendo sujeitar as suas causas ao Desembargo do Paço". (LAHON, 1999B: 129)

No ano de 1772, a Irmandade de Jesus Maria José dos homens pretos, sita no Convento de Jesus, encaminhou ao Desembargo do Paço uma petição em defesa do irmão Vicente Correia, casado com Josefa Maria, e pai de Anna Rita, Joana Maria da Encarnação e Francisco José. A irmandade solicitava que o proprietário de Vicente Correia, Félix Coutinho de Azevedo, fosse impedido de vender Vicente e sua família para o Pará ou para o Maranhão. A solicitação baseava-se no privilégio concedido primeiramente à Irmandade do Rosário do Convento de São Domingos, ainda no século XVI, de "resgatar os irmãos cativos que os senhores quisessem vender para fora do reino" ${ }^{14}$.

$O$ resgate de confrades, mesmo contra vontade dos senhores, foi o privilégio mais polêmico alcançado pelas confrarias negras em Portugal. Concedido à confraria do Convento de São Domingos no século XVI, nos séculos seguintes, foi estendido a algumas e reivindicado por várias confrarias de Lisboa e de outras partes do país ${ }^{15}$. Os irmãos de São Benedito e Nossa Senhora de Guadalupe encaminharam petição do Desembargo do Paço reivindicando os mesmos privilégios das Irmandades do Rosário dos Conventos do Salvador, da Santíssima Trindade, de Santa Joana e da Graça 
"não só para exercitarem as meritórias obras de libertarem seus irmãos que viviam nos cativeiros, pagando a seus senhores a justa estimação deles, mas para todas as mais, de que os privilégios se compunham"16. A resposta da Mesa do Desembargo é expressiva dos constrangimentos sofridos pelas irmandades negras em Portugal na luta pela liberdade de seus irmãos. A Mesa considerou em seu parecer que:

A graça que os suplicantes requerem, de algum modo impede a livre faculdade que os Senhores dos Escravos tem para os venderem, a quem lhes parecer (...). Será conveniente se verifique somente nos dois casos: ou em que os ditos Senhores dos Escravos os tratem com excessos de castigos corporais, que se façam ofensivos das regras da humanidade; ou quando por ódio e vingança queiram vender para fora do domínio do Reino. ${ }^{17}$

No decorrer dos séculos, os privilégios régios, sobretudo no que dizia respeito ao resgate dos irmãos cativos, sofreram várias restrições, sempre a favor do direito de propriedade dos senhores. Após o século XVII, o privilégio de resgate dos irmãos cativos esteve sempre condicionado aos maus tratos ou à "venda que afastava o irmão para longe de Lisboa ou barra fora, na maioria das vezes para o Brasil" (LAHON, 1999B:130).

A comprovação dos maus tratos não era coisa fácil. Afinal, era a palavra do senhor contra a do escravo. O embate da Irmandade do Rosário do Convento da Trindade, a favor da liberdade do irmão Luiz João José Ozare, é um exemplo desta dificuldade. Luiz João José Ozare era escravo do tenente João Batista, que prestava serviço nas naus da Armada Real. Na condição de cativo do tenente, Luís João acompanhou seu senhor em viagens às Índias e América, chegando a viver por algum tempo na cidade da Bahia. $\mathrm{Na}$ petição de resgate, a irmandade alegava que o irmão Luís João sofria maus tratos por parte do senhor, alegava também a necessidade de seus serviços para a irmandade. O requerimento dos suplicantes foi, no entanto, escusado. Em sua defesa, ao que tudo indica, acatada pela Mesa do Desembargo, entre outros argumentos, o 
tenente João Batista alegou que seu escravo nunca havia se assentado na irmandade que requeria o resgate - o que, por princípio, inviabilizaria todo o processo ${ }^{18}$. Nunca saberemos se Luiz João realmente forjou seu assento na irmandade para se beneficiar do privilégio do resgate de cativos. Verdade ou não, o certo é que este foi o caminho que ele encontrou para chegar à liberdade.

Também não foi possível saber qual a decisão final da mesa sobre o resgate de Vicente e sua família, ameaçados de serem vendidos para as terras do Pará ou Maranhão ${ }^{19}$. Sabe-se, no entanto que, no final do século XVIII, escravos irmãos das irmandades de Lisboa eram vendidos para o Brasil, pois os ministros do Desembargo entendiam que "os Brasis são conquistas deste Reino" 20.

A maioria das histórias registradas nos numerosos processos de resgate de irmãos cativos não tem final feliz para os requerentes. Na verdade, para a maioria delas, nem sequer é possível saber realmente qual foi o final. O que chama a atenção, no entanto, é o número de petições e a insistência das irmandades nos processos de resgate de irmãos cativos. Este fato indica que as irmandades católicas constituíram um dos mais, senão o mais importante canal de defesa dos escravos em Portugal. No decorrer dos séculos XVIII e XIX, esta informação circulava o Atlântico. Após a promulgação da lei de 19 de setembro de 1761, escravos oriundos do Brasil na companhia de seus senhores, particularmente após 1822, recorreram às irmandades para garantir sua liberdade ${ }^{21}$.

Independente da invocação, as irmandades de negros em Portugal foram lugares de proteção e apoio jurídico dos irmãos escravos e libertos. É preciso ressaltar, no entanto, que além da precedência, a invocação do Rosário foi a mais popular entre a população negra em Portugal. Talvez, por esta razão, a invocação foi se associando à proteção e defesa das populações negras espalhadas pelo Império. Depois de ser compulsoriamente obrigado a atravessar o Atlântico, encontrar uma irmandade do Rosário poderia ser um conforto para muitos. 
“ÁFRICA EM PORTUGAL"...

\section{Senhora do Rosário dos pretos em Portugal}

Como devoção dominicana no seu princípio, desde o século XVI, o Rosário passou a ser uma das principais invocações do movimento de conquista e conversão dos gentios, passando então a ser divulgada por todas as ordens religiosas missionárias. O sucesso do Rosário entre os "gentios conversos" explica-se, num primeiro momento, pelo destaque desta invocação nas atividades missionárias. Posteriormente, os próprios africanos e seus descendentes parecem ter reconhecido nas irmandades dedicadas à senhora Mãe de Deus, com a invocação do Rosário, um espaço próprio e reservado.

A devoção ao Rosário surgiu no início do século XIII, no contexto dos combates às "heresias" modernas. Conta a tradição católica que Domingos de Gusmão, religioso dominicano e pregador na região de Albi, sul da França (local onde se proliferam os "heréticos albigenses e cátaros"), teve uma revelação da Virgem que lhe ensinou um método de oração no qual seria invocada com a ajuda de contas unidas por um cordão (SOUZA, 2001:382). A devoção esteve praticamente esquecida até a segunda metade do século XV. Neste período, os dominicanos alemães, temerosos das ameaças provocadas pelo cisma precursor da Reforma Protestante, decidiram revigorar a devoção revelada a Domingos de Gusmão. Em 1475 a primeira confraria do Rosário foi fundada em Colônia, na Alemanha (SOUSA, 1977: 353-354). Após a batalha de Lepanto, em outubro de 1571, embate que encerrou definitivamente o domínio dos turcos no mar Mediterrâneo, Nossa Senhora do Rosário passou a ser associada à luta dos católicos contra os infiéis, sendo "escolhida" como padroeira das novas conquistas espirituais (SOUZA, 2004: 40).

Em Portugal a devoção ao Rosário já estava estabelecida no final do século XV. Em 1490, "os nobres e o povo acudiram à intercessão da Virgem, por ocasião da peste que nesse ano assolou Lisboa, e logo resolveram levantar, como levantaram, uma capela com grande aparato" (TINHORÃO, 1997: 14). Desde 
então, o culto ao Rosário foi muito popular em Portugal. Foi adotada como padroeira de vários segmentos sociais e profissionais, como os marinheiros no Porto. Em todo o reino criaram-se igrejas dedicadas a seu culto. As irmandades sob sua invocação foram as mais importantes e numerosas, rivalizando com as confrarias do Santíssimo Sacramento e das Almas (SCARANO, 1978: 39-40).

No século XVIII, o culto ao Rosário se espalhara por todo Portugal, já então, havia se estabelecido uma associação entre esta devoção e a população de escravos e libertos do Reino. A maioria das irmandades de negros de Lisboa e do restante do país era dedicada a Nossa Senhora do Rosário. Algumas, como a Confraria de N. S. do Rosário e dos Santos Reis Magos, em Lisboa, ou a de N.S. do Rosário e São Benedito, no Porto, associavam a Virgem a outras devoções; ainda assim, o número de confrarias dedicadas ao Rosário em todo o país atesta a primazia da devoção ${ }^{22}$.

Parece mesmo que a população negra foi se apropriando do culto ao Rosário como prerrogativa particular. Segundo Frei Agostinho de Santa Maria, isto se passou concretamente com a imagem que se encontrava no Mosteiro da Santíssima Trindade em Lisboa. Neste convento, na capela dos Reis, estava colocada uma imagem de Nossa Senhora praticamente esquecida dos fiéis. "Depois dessa bem culpável frieza e esquecimento para com aquela Santíssima Imagem da Mãe de Deus, ascendeu o mesmo Deus um grande fogo nos corações dos pretinhos e eles tomaram muito por sua conta servir à Mãe de Deus e lhe deram o título do Rosário"23.

Há muito, os estudiosos vêm buscando interpretar as razões desta associação tão estreita e duradoura. Saunders lançou a hipótese de que "a natureza semi-mágica, quase talismânica do rosário pode ter constituído um apelo aos africanos acostumados a feitiços" (SAUNDERS,1982: 206). O uso mágico do rosário, assim como de outros símbolos cristãos, não seria exatamente uma exclusividade da devoção dos negros, como têm demonstrado os diversos estudos sobre as práticas religiosas populares na Península Ibérica e na América 
Portuguesa $^{24}$. Entretanto, não deixa de ser uma hipótese interessante considerar uma releitura africana do Rosário, de modo semelhante à que ocorreu com outros objetos sagrados do cristianismo (Swett, 2007: 229), (Horta, 1997: 307-308).

José Ramos Tinhorão também propôs uma interpretação de difícil sustentação, se é que assim podemos dizer, sobre a primazia da devoção ao Rosário entre os negros em Portugal e nas Américas. Segundo Tinhorão, "os negros se fixaram em Nossa Senhora do Rosário pela ligação estabelecida com seu orixá Ifá, através do qual era possível consultar o destino atirando soltas ou unidas em rosário as nozes de uma palmeira chamada okpê-lifa". (TINHORÃO, 1997: 138) A tese de Tinhorão peca principalmente pelo anacronismo e pelo equívoco no tocante ao tráfico atlântico de escravos.

A importância e vigor do culto ao Rosário são anteriores à presença dos grandes contingentes de cativos jejes e iorubás entre as populações negras nas Américas. Ainda no caso da Península Ibérica, nenhum dado conhecido permite confirmar a relevância destas populações no âmbito das irmandades negras no decorrer dos séculos XVI a XVIII. Além disso, a hipótese de Tinhorão, no fundo, está sustentada na velha tese da integração do negro ao catolicismo por meio de "justaposição de exterioridades". Nesse caso, o que conta, é o efeito sedutor da aparência do rosário e não a experiência histórica de elaboração da identificação.

Nesse sentido, Lahon observa que a associação em irmandades de devoção ao Rosário não foi, nos primeiros tempos, uma escolha dos negros.

$\mathrm{Na}$ época, as confrarias religiosas eram muito seletivas. Recrutavam seus membros entre um grupo homogêneo, no qual o estatuto social e profissional constituía um critério determinante. (...) Cada membro devia contribuir financeiramente, o que concorria para afastar os mais desprovidos. Em resumo, as confrarias eram instituições "fechadas" e ninguém aí entrava sem satisfazer vários critérios de seleção, entre eles o de limpeza de sangue. (LAHON, 1999A: 59). 
As confrarias do Rosário, por regra estabelecida em sua formação, não levavam em consideração critérios de riqueza e estatuto social. Admitia todos os cristãos "assim homens, como mulheres, de qualquer estado e condição que sejam, grandes, e pequenos". Ninguém deveria ser obrigado a pagar coisa alguma para entrar na confraria de modo que nenhum pobre deixasse de sê-lo por estes motivos ${ }^{25}$.

Quero crer que o espaço demarcado foi, aos poucos, tornando-se um espaço reconhecido. A identificação foi-se dando na experiência cotidiana da escravidão. Neste ambiente, as irmandades jogaram um papel fundamental na defesa dos interesses das populações escravas e libertas. Por outro lado, a manutenção destes espaços possibilitou uma vivência do catolicismo, muito provavelmente, marcada por valores africanos. Infelizmente, os registros produzidos pelos irmãos negros não deixam escapar quase nada sobre suas práticas devotas mais particulares. Também neste aspecto é possível falar de uma experiência atlântica das irmandades de negros.

\section{O Santo Preto de Palermo e outras devoções negras no Reino}

Em Portugal, a primeira irmandade dedicada a São Benedito foi instituída no ano de 1609 no Mosteiro de Santana , em Lisboa (LAHON, 1999B: 136). Não consta que esta tenha sido uma irmandade preferencialmente de negros, como a que se formou no convento de São Francisco, na mesma cidade de Lisboa $^{26}$. A instituição da devoção na Bahia colonial sugere que a devoção ao santo preto de Palermo também tenha sido popular entre os brancos.

Os frades do Convento de São Francisco na Bahia atribuíram a São Benedito um acontecimento milagroso, ocorrido no ano de 1623. Frei Bernardino de Santiago, guardião da casa do Seráfico Padre São Francisco da cidade da Bahia, levou a Imagem de São Benedito a um enfermo que estava no último dia de vida. Após a encomendação o moribundo "lançou um bicho à maneira de cobra pequena, que lhe parecia tinha furado no 
coração, de que muito se queixava, e mandou fazer uma de prata à maneira da que botara, e trouxe a esta casa em memória do milagre". O enfermo, de nome Luís Ferreira Pereira, era natural da cidade do Porto, onde residiu por muitos anos antes de mudar-se para a América Portuguesa. No Porto, foi mordomo de São Benedito, donde se explica sua devoção ao santo ${ }^{27}$. A devoção de Luís Ferreira Pereira é apenas mais uma confirmação da popularidade do Santo - também entre os brancos - em terras lusitanas, principalmente pelos seus poderes taumaturgos ${ }^{28}$. Segundo os estatutos da antiquíssima Irmandade de N.S. do Rosário e São Benedito da cidade do Porto, reformados no ano de 1781, os brancos eram admitidos em lugares de destaque na confraria. Os cargos de juiz, tesoureiro, escrivão e mordomos deveriam ser ocupados por "homens dos principais da cidade (...) todos brancos e abonados" 29 .

São Benedito, nascido na Sicília de pais mouros do norte da África, foi Frade Menor da Observância num convento perto de Palermo, morreu em 1589 sendo beatificado oficialmente em 1763 e canonizado no início do século XIX, em 1807 (BUTLER, 1984: 48-50). A popularidade de sua devoção entre os negros no Império Português, precede e ultrapassa o aval romano.

Algumas ordens religiosas tiveram um importante papel na propagação de devoções adotadas pela população negra no período colonial. A importância dos franciscanos na propagação do culto a São Benedito justifica-se, primeiramente, por ser este santo um religioso desta ordem. Em Lisboa e na cidade do Porto, bem como em outras partes da América Portuguesa, foi possível identificar irmandades dedicadas a São Benedito em conventos franciscanos ${ }^{30}$.

São Benedito não foi o único santo preto cultuado na Península Ibérica. No imaginário cristão anterior à expansão portuguesa na costa atlântica da África, personagens e santos negros ligados ao reino cristão etíope, já tinham sido incorporados no projeto da Cristandade Ocidental. Assim, "antes de serem cultuados pelos negros africanos, o foram pelos brancos europeus" (PINTO, 2000: 61). 
No início do século XVIII, havia uma imagem de Santa Ifigênia colocada num dos altares da igreja do Carmo em Lisboa. A imagem da santa africana era "continuamente buscada de muitas pessoas, a quem [consta ter feito] portentosos benefícios" ${ }^{31}$. Nesta mesma igreja do Carmo, um seleto grupo de senhoras ilustres instituíram uma confraria para devoção especial da princesa do reino da Núbia. Para estímulo dos fiéis e propagação da devoção, na portaria do Convento dos carmelitas em Lisboa estava à venda o livro do Frei José Pereira de Santa Ana sobre a vida de Santa Ifigênia com o título de Segundo Atlante de Etiópia Santa Ifigênia ${ }^{32}$. Numa edição mais condensada e popular vendia-se também "um livrinho com o título de Mestre da Morte e Medianeira da vida eterna, onde está a devoção, que se costuma fazer a esta santa" ${ }^{33}$.

A devoção teve início na cidade de Cadiz, na Espanha:

onde na Igreja paroquial da Virgem Senhora do Rosário existe de Santa Ifigênia um bem paramentado altar, no qual com louvável freqência de toda Nobreza, e Plebe se lhe dedicam, não sé os obséquios anuais, e estrondosas festas, mas também os quotidianos de incessantes votos, e intermináveis rogativas. ${ }^{34}$

Assim como Ifigênia, Santo Elesbão foi uma devoção estimulada pelos carmelitas. Segundo a tradição carmelita, era natural da Etiópia e $46^{\circ}$ neto do Rei Salomão e da Rainha de Sabá, sendo imperador de seu país no século VI:

Foi creditada a Elesbão a extensão do reino cristão da Etiópia até o lado oposto do Mar Vermelho, impondo-se aos árabes do Iémen. (...) Ao final da vida, o imperador etíope teria renunciado ao trono em favor de seu filho, doando sua coroa à Igreja e tornando-se anacoreta. (OLIVEIRA, 2002: 157).

Elesbão também foi homenageado com um altar na igreja do convento do Carmo em Lisboa, em torno do qual se organizou uma irmandade para cuidar de sua devoção ${ }^{35}$. 
Outro santo da modernidade, tal qual o de Palermo, foi muito conhecido e venerado em Portugal. Segundo a tradição devota, Santo Antônio de Categeró ou Catalagerona (corruptela de Cataljirona, cidade da Sicília) é o mesmo Santo Antônio de Noto, igualmente mulçumano convertido ao catolicismo, eremita e $3^{\circ}$ franciscano ${ }^{36}$. Para Lahon, esta identificação foi fruto de uma confusão que se instaurou no Brasil e mesmo em Portugal, uma vez que, para este estudioso, trata-se de dois personagens distintos, ainda que contemporâneos e donos de biografias muito semelhantes (LAHON, 1999B:136) A literatura religiosa de cunho confessional, no entanto, corrobora a tradição devota (GUASTELA, 1986) ${ }^{37}$.

A imagem do Santo Antônio preto, representado com o Menino Jesus no colo, tal qual a capa do primeiro compromisso da Irmandade de Santo Antônio de Categeró na cidade da Bahia, foi muito popular em Portugal ${ }^{38}$. No final do século XVIII, o sacerdote sueco Carl Israel Ruders presenciou uma das mais importantes procissões do calendário festivo de Lisboa. $\mathrm{Na}$ procissão de Santo Antônio de Lisboa, desfilavam pelas ruas "uma grande quantidade de imagens, algumas representando Santo Antônio e a Mãe de Deus com o Redentor nos braços". Dentre as inúmeras imagens, a de um santo preto era um dos atrativos da procissão. "O andor deste santo preto, de lábios grossos, era levado por negros e acompanhado por padres da mesma cor, seguidos de uma multidão de pretos e mulatos" ${ }^{39}$. É provável que o santo preto que desfilava na procissão do patrono de Lisboa fosse o particular Santo Antônio dos negros. Além da afinidade epidérmica, a popularidade do Santo Antônio Preto em Portugal provavelmente se relaciona com a importância deste santo no catolicismo centro-africano ${ }^{40}$.

A devoção ao Santo Antônio preto também foi conhecida no Reino de Angola. Em seu testamento datado de 21 de dezembro de 1789, José Manuel, comerciante na cidade de Benguela, determinou que:

Sendo seu falecimento nesta cidade, será meu corpo amortalhado em mortalha branca segundo o costume da terra, e conduzido no 
esquife de Santo Antônio de Catalagerona, acompanhado pelos seus irmãos para a igreja da Freguesia de Nossa Senhora de Populo, onde quero ser sepultado. ${ }^{41}$

Muitos fatores pesavam na escolha dos santos patronos. Entre os negros, a afinidade epidérmica e geográfica não pode ser desconsiderada. A valorização dos santos negros, ainda que humildes servos como São Benedito e Santo Antônio de Categeró, não deixava de ser um campo aberto para reinterpretações da mensagem católica. Boschi também sugere que a identidade com as "agruras" dos santos foi importante elemento para a identificação e adoção dos patronos pelas irmandades de negros (BOSCHI, 1986: 26).

Sem deixar de levar em conta as escolhas efetuadas pelos africanos e seus descendentes, é importante também considerar que as escolhas foram, muitas vezes, circunscritas. O investimento das ordens religiosas na propagação de patronos negros para os negros, como sugeri acima com relação aos franciscanos e carmelitas, é uma limitação considerável.

Mas, isto não torna menor o esforço de apropriação dos santos católicos pelos africanos e seus descendentes. No continente africano, as imagens sagradas do rito católico, incluindo neste rol as imagens de santos, foram interpretadas, num primeiro momento, como objetos mágicos e poderosos. No século XVII, entretanto, já circulava entre os conversos africanos a crença no santo - parente. Conta-nos Cadornega que, naquele tempo, corria em Angola uma "lenda" de que São Benedito era natural daquele reino, mais precisamente da cidade de Quissama ${ }^{42}$.

Em Portugal e na América, os santos pretos ganharam estatuto de ancestrais poderosos e igualmente reconhecidos no mundo dos senhores brancos. Os irmãos de São Benedito de Ribeirão do Carmo em Minas Gerais deixaram um precioso registro que bem ilustra esta interpretação.

Quão admirável seja Deus em seus Santos notoriamente se manifesta no prodigioso sujeito de São Benedito, que bem se 
pode com razão afirmar, que na graça Divina lhe saiu a este santo a sorte em preto; e que não obstante o escuro dos acidentes, foi muito esclarecido em todo gênero da virtude, fazendo um protótipo e exemplar para nós a gente de cor preta; para que nos animássemos ao exercício de obras espirituais que conduzem para o senhor, que esperamos de conseguir a bem-aventurança. $\mathrm{E}$, portanto, agradecidos os homens e mulheres pretos a um santo que tão bom exemplo e tanta honra deu aos parentes. ${ }^{43}$ (grifo da autora)

Desse modo, o parentesco com o santo re-elabora as complicadas relações sociais de parentesco e ganha moldes, aparentemente mais simples. Assim, a interpretação do santoparente sugere que a apropriação negra das devoções católicas foi condição essencial para sua aceitação e propagação entre os negros nos três continentes.

\section{Conclusão}

A história das irmandades e das devoções negras é uma "porta de entrada" bastante promissora para o estudo da presença africana e crioula na Portugal setecentista. Aspectos diversos como: identificações e re-elaborações étnicas; resistência e arranjos, pessoais e coletivos, diante da escravidão e práticas religiosas particulares emergem de uma documentação aparentemente árida, uma vez que se destina às autoridades civis para fins muito específicos. De forma semelhante ao que ocorre na América Portuguesa, escassos são os registros produzidos pelos irmãos negros, dando conta da organização e vida coletiva, que sobreviveram à ação do tempo. Entretanto, as iniciativas gestadas nos últimos tempos têm demonstrado que a pesquisa neste campo promete resultados promissores, sobretudo, na perspectiva de colaborar com a investigação da história da escravidão e da presença africana em Portugal de todas as épocas. Num contexto de "reafirmação" do racismo e do xenofobismo em toda a Europa, fomentar uma 
reflexão histórica sobre o tema pode contribuir muito positivamente em favor do reconhecimento de direitos e dívidas seculares.

\section{Referências Bibliográficas}

BOSCHI, Caio. Os leigos e o poder. Irmandades leigas e política colonizadora em Minas Gerais, São Paulo: Editora Ática, 1986.

BOXER,Charles. A Igreja e a expansão Ibérica, Lisboa: Edições 70, 1989. BRÁSIO, Antonio. Os Pretos em Portugal. Lisboa: Agência Geral das Colônias, 1944.

BUTLER, Alban. A vida dos santos. Petrópolis : Vozes, 1984.

CASTRO HERIQUES, Isabel. Percursos da modernidade em Angola. Dinâmicas comerciais e transformações sociais no século XIX. Lisboa: Instituto de Investigação Científica Tropical/Instituto de Cooperação Portuguesa, 1997.

FONSECA, Jorge. "Senhores e escravos no Algarve (1580-1700)" In: Anais do Município de Faro, Faro, n. 26, pp. 151-176,1996.

FONSECA, Jorge Fonseca, Escravos em Évora no século XVI, Évora: Câmara Municipal de Évora, 1997.

GUASTELA, Salvatore. Santo Antônio de Categeró: sinal profético do empenho pelos pobres. São Paulo: Paulus, 1986.

GUIMARÃES, Isabel Sá. As Misericórdias portuguesas de D. Manuel I a Pombal, Lisboa: Livros Horizonte, 2001.

HORTA, José da Silva. Africanos e portugueses na documentação inquisitorial, de Luanda e Mbanza Kongo (1596-1598). In: Seminário. Encontro de Povos e Culturas em Angola, 1997. Actas do Seminário. Luanda:Comissão Nacional para as comemorações dos descobrimentos portugueses, 1997, pp.301-321.

LAHON, Didier. Esclavage et Confréries Noires au Portugal durant l'Ancien Régime (1441-1830). These pour l'obtention du grade de Docteur de L' ehess, Paris, Ecole Des Hautes Etudes En Sciences Sociales, 2001.

LAHON, Didier. O negro no coração do Império. Uma memória a resgatar - Séculos XV - XIX, Lisboa: Secretariada Coordenador dos Programas Multicultarais - Ministério da Educação, 1999 A.

LAHON, Didier. "As irmandades de escravos e forros". In: Os Negros em Portugal. Catálogo da exposição. Lisboa: Comissão Nacional para as Comemorações dos Descobrimentos, 1999 B. 
LARA, Silvia Hunold. "A escravidão africana na historiografia lusobrasileira: balanço e perspectivas". In: J. Jobson Arruda e Luís Adão da Fonseca (orgs.) - Brasil-Portugal: História, agenda para o milênio. Bauru, EDUSC/FAPESP/ICCTI, 2001, pp.387-404.

LOVEJOY, Paul. "A jornada de Mahommah Gardo Baquaqua para as Américas". Afro-Ásia, 27, pp.9-39, 2006.

OLIVEIRA, Anderson José Machado de. "Os Santos Pretos Carmelitas": culto dos santos, catequese e devoção negra no Brasil Colonial. Niterói, 2002. Tese (Doutorado em História), UFF.

PENTEADO, Pedro Penteado. "As confrarias portuguesas na época moderna: problemas, resultados e tendências de investigação". Separata de Lusitânia Sacra, $2^{a}$. série, (1995).

PINTO, Tânia Maria de Jesus. Os negros cristãos católicos e o culto aos santos na Bahia Colonial. Salvador, 2000. Dissertação (Mestrado em História), PPGH/ UFBA.

SAUNDERS, A C.de C. M. História Social dos escravos e libertos negros em Portugal, (1441-1555). Lisboa: Imprensa Nacional - Casa da Moeda, 1982.

SCARANO, Julita. Devoção e Escravidão. A Irmandade de N.S. do Rosário dos Pretos do Distrito Diamantino no Século XVIII. São Paulo: Editora Nacional, 1978.

SOARES, Mariza de Carvalho. "Mina, Angola e Guiné: nomes d África no Rio de Janeiro setecentista". Tempo, Niterói, 6, pp.73-93,1998.

SWETT, James. Recriar África. Cultura, parentesco e religião no mundo afro-português (1441-1770). Lisboa: Edições 70, 2007.

SOUSA, Frei Luis. História de São Domingos. Vol.1. Porto: Lello e Irmão Editores, 1977.

SOUZA, Juliana Beatriz Almeida de. "Viagens do Rosário entre a Velha Cristandade e o Além-Mar", Estudos Afro-Asiáticos, Ano 23, 2, pp. 37995, 2001.

TINHORÃO, José Ramos. Os Negros em Portugal. Uma presença silenciosa. Lisboa: Editorial Caminho, 1997.

THORNTON, John. The Kongolese Saint Anthony, Dona Beatriz Kimpa Vita and the Antonian Movement, 1684-1706. Cambridge: Cambridge University Press, 1998.

\section{Abreviaturas}

AHU - Arquivo Histórico Ultramarino

AN/TT - Instituto dos Arquivos Nacionais - Torre do Tombo

BNL - Biblioteca Nacional de Lisboa 
REGINALDO, Lucilene. "Africa in Portugal": slavery, religious devotion and black brotherhoods during the $18^{\text {th }}$ century Portuguese Kingdom. História, v.28, n.1, p.289-320, 2009.

\begin{abstract}
The following article discusses the history of the brotherhoods that brought together slaves and free Africans as well as their descendants in Portugal during the $18^{\text {th }}$ century. In this way, the article considers a more general panorama of the history and the historiography of slavery and the African presence in Portugal. It tries to understand the contextual appearance and the singularities of the black brotherhoods within the setting of the Portuguese lay fraternities. In conclusion it highlights the importance of these organizations in the constitution of community life and in defense of the interests of the black slave and free population in the kingdom of Portugal.
\end{abstract}

Keywords: Slavery; Brotherhoods, Religion, Portugal.

\title{
NOTAS
}

${ }^{1}$ Além dos autores que são citados e comentados neste artigo, foi possível identificar não mais que uns poucos estudos sobre o tema da escravidão em Portugal. Dentre os mais recentes destaco: Maria do Rosário Pimentel Viagem ao fundo das consciências. A escravatura na época moderna. Lisboa: Ed. Colibri, 1995 e João Pedro Marques. Os sons do silêncio: o Portugal de Oitocentos e a abolição do ráfico de escravos. Lisboa: Instituto de Ciências Sociais da Universidade de Lisboa, 1999. Daniela Calainho. Metrópole das Mandingas. Religiosidade negra e Inquisição portuguesa no Antigo Regime. (Tese de Doutorado) Rio de Janeiro: Universidade Federal Fluminense, 2000.

${ }^{2}$ Pe. D. Raphael Bluteau. Vocabulário portuguez e latino. Coimbra, Collegio das Artes da Companhia de Jesus, 1712. (Ed. fac-simile, CDRom, Rio de Janeiro, UERJ, s.d.). Verbetes gentio; gentilismo.

3 "De um ponto de vista mais secularizado, o escravo passa a ser identificado não por sua contribuição ao projeto de expansão cristã, mas por sua importância no quadro dos conflitos em território africano e das rotas e portos de embarque do tráfico negreiro". Mariza de 
Carvalho Soares. "Mina, Angola e Guiné: nomes d África no Rio de Janeiro setecentista".p. 81

${ }^{4}$ Pe. Baltazar Teles, Crônica da Companhia de Jesus em Portugal. Segunda parte, Livro IV, Lisboa 1647, pp. 223-224, Apud: Os Negros em Portugal - Catálogo da Exposição, Lisboa, Comissão Nacional para as comemorações dos descobrimentos, 1999, p.133.

519 de Novembro de 1706, Consulta da Câmara de Lisboa, in: Os Negros em Portugal, pp. 122-123.

6 Certas atividades de ganho, tanto masculinas como femininas, obtiveram reconhecimento legal e normatização de suas funções, como os serviços de caiação e lavagem de casas. Ver: Lahon, Os negros no coração do Império, p. 52.

7 BNL. Cristovam Rodrigues Oliveira, Sumário que brevemente se contem algumas coisas assim Eclesiásticas, como Seculares, que há na cidade de Lisboa (1551), Lisboa, Oficina de Miguel Rodrigues, 1760.

8 BNL. Ignácio Machado Barbosa, História crítico-cronológica da instituição da festa, procissão e ofício do Corpo Santíssimo de Cristo no Venerável Sacramento da Eucaristia, Lisboa, Oficina de Francisco Luiz Ameno, 1769, pp. 170-172,

${ }^{9}$ Ignácio Machado Barbosa, História crítico-cronológica da instituição da festa, procissão e ofício do Corpo Santíssimo de Cristo no Venerável Sacramento da Eucaristia, p. 170.

${ }_{10}$ Pe. Baltazar Teles, Crônica da Companhia de Jesus em Portugal. Segunda parte, Livro IV, pp. 223-224, Apud: Os Negros em Portugal Catálogo da Exposição,

11 IAN/TT, Desembargo do Paço, maço 215, doc. 3, Petição dos Confrades da Confraria de Nossa Senhora do Rosário dos Homens pretos, solicitando provisão de licença para pedirem esmola para festa da Senhora, 19-08-1783maço 215, do.c 3.

${ }^{12}$ Primeiro é preciso considerar as limitações impostas pelos registros documentais. Lahon, após exaustivas investidas, afirma não ter encontrado livros de assentos de irmãos, ou outros registros de identificação individual dos associados. Este tipo de registro permite observar a vigência de critérios, explícitos ou implícitos, de restrição à entrada ou acesso aos cargos de mesa. Da mesma forma, os raros compromissos preservados, tampouco fazem menção a critérios étnicos ou de procedência na entrada de novos associados.

${ }^{13}$ Sobre os reinados negros em Portugal ver: Maria do Rosário Pimentel Viagem ao fundo das consciências. A escravatura na época moderna. Lisboa: Ed. Colibri, 1995. 
${ }_{14}$ IAN/TT, Desembargo do Paço, Maço 1016, doc. 17. Parecer do Corregedor do Civil da cidade escusando a petição da Irmandade de Jesus Maria José dos Homens Pretos, sita no Convento de Jesus de Lisboa, 08-07-1772.

15 IAN/TT, Desembargo do Paço, Maço 1006, doc. 31, Petição da Irmandade de N.S. do Rosário dos homens pretos cita no Mosteiro da Anunciada, solicita confirmação do privilégio para poderem comprar a liberdade de seus irmãos que os senhores quiserem vender para fora do Reino. 18-11-1756.

16 IAN/TT, Desembargo do Paço, Maço 1345, doc.19. Petição da Irmandade de São Benedito e N.S. de Guadalupe sita no Convento de São Francisco de Lisboa, 1778. Pedem os mesmos privilégios das irmandades do Rosário dos Homens pretos de Lisboa. Anexos: Certidões dos privilégios concedidos em cartas e alvarás as Irmandades do Rosário dos Conventos de São Domingos, do Salvador, da Trindade, de Santa Joana, da Graça e de São Francisco de Évora.

${ }^{17}$ IAN/TT, Maço 2109, doc. 23, 1778. Parecer da Mesa do Desembargo do Paço à respeito da petição da Irmandade de São Benedito e N. S. da Guadalupe, ereta no Convento de São Francisco da cidade de Lisboa, 03-03-1779. .

${ }^{18}$ IAN/TT, Maço 1079, Desembargo do Paço, doc. 7, Irmandade de N. S. do Rosário dos homens pretos do Convento da Santíssima Trindade, em favor do irmão Luíz João José Ozare, escravo de João Batista.

19 IAN/TT, Desembargo do Paço, Maço 1016, doc. 17.Parecer do Corregedor do Civil da cidade escusando a petição da Irmandade de Jesus Maria José dos Homens Pretos, sita no Convento de Jesus de Lisboa, 08-07-1772.

20 IAN/TT, Desembargo do Paço, Maço 2091, doc. 29. Petição da Irmandade do Rosário a Resgatada dos homens pretos do Convento da Santíssima Trindade em Lisboa, 20-09-1761.

${ }^{21}$ Lei de proibição de importação de escravos em Portugal. Ordenava ainda que todos os cativos que desembarcassem nos portos portugueses "fique pelo benefício libertos e forros sem necessitarem de outra alguma carta de manumissão, ou alforria, nem de outro algum despacho, além das certidões dos Administradores, oficiais, das Alfândegas dos lugares que portarem (...)". Negros em Portugal, pp. 87-88.

${ }^{22}$ A partir da segunda metade do século XVI, são eretas, no interior de Portugal, inúmeras irmandades dedicadas ao Rosário de Nossa Senhora exclusivas de negros escravos e libertos. Uma listagem 
completa, além de exaustiva, correria o risco de omissões importantes. Apenas para mencionar algumas das mais importantes cito as irmandades do Rosário localizadas em: Évora, Elvas, Estremoz, Montemor - o Novo, Vila Viçosa, Lagos, Faro, Setúbal, Alcácer do Sal e Moura. Ver: Frei Agostinho de Santa Maria, Santuário Mariano; Antonio Brásio, Os Pretos em Portugal. Lisboa, Agência Geral das Colônias, 1944, pp. 99-104; Lahon, O negro no coração do Império, p. 70.

${ }^{23}$ Frei Agostinho de Santa Maria. Santuário Mariano e História das Imagens Milagrosas de Nossa Senhora, e das milagrosamente aparecidas, em graça dos Pregadores \& devotos da mesma Senhora. Lisboa, Na Oficina de Antonio Pedroso Galrão, 1707. Tomo VII.

${ }^{24}$ Ver, entre outros, Laura de Mello e Souza, O Diabo na Terra de Santa Cruz. São Paulo, Companhia das Letras, 1995.

${ }^{25}$ BNL. Fr. Nicolau Dias. Livro do Rosário de Nossa Senhora. (Lisboa: Na Casa de Francisco Correa, (1573). Lisboa: Biblioteca Nacional, 1982. Edição fac-similada da $1 .{ }^{a}$ edição, pp. 30-31.

26 Uma irmandade dedicada à Nossa Senhora de Guadalupe foi instituída no Convento de São Francisco de Lisboa na década de 1580. Anos mais tarde, esta mesma irmandade adota juntamente com a Virgem de Guadalupe a invocação à São Benedito. É possível que esta adoção tenha sido conseqüência da popularidade do santo entre os escravos negros em Portugal.

${ }^{27}$ Frei Antonio Santa Maria Jaboatão. Novo Orbe Seráfico Brasílico ou Crônica dos Frades Menores da Província do Brasil [1761]. Rio de Janeiro, Tipografia Brasiliense de Maximiliano Gomes, 1859, pp. 91-94; Compromisso da Irmandade de Nossa Senhora do Rosário e São Benedito no Convento de São Francisco na Cidade do Porto, IAN/TT, OFM - Província de Portugal, São Francisco do Porto, Livro 3.

${ }^{28}$ Foi publicado em Lisboa no ano de 1754, de autoria de um religioso nascido na cidade de São Paulo - Brasil, um curioso receituário "das vocações dos Santos para remédio de todas as enfermidades". Nesta publicação, recomenda-se invocar São Benedito como remédio para engasgo com ossos, espinhos ou espinhas de peixe. Botica preciosa e tesouro precioso da Lapa. Em que se acham todos os remédios para o corpo, para alma e para vida...Lisboa, 1754.

${ }^{29}$ Adição e reforma feita aos capítulos do Compromisso, ou Estatutos da Irmandade de N.S. do Rosário e São Benedito no Convento de São Francisco da cidade do Porto (...) feita neste presente ano de 1781, capítulo 5. ․, IAN/TT, Província de Portugal - São Francisco do Porto. 
${ }^{30}$ No Bispado de Pernambuco foram duas as irmandades dedicadas a São Benedito eretas em conventos da Ordem de São Francisco: no Convento de Santo Antônio na Vila de Ipojuca e no Convento de Santo Antônio da cidade do Recife. IAN/TT, Chancelarias Antigas - Ordem de Cristo, Livro 283, fls. 163-167. Compromisso da Irmandade de São Benedito no Convento de Santo Antônio da Vila de Ipojuca.

Compromisso da Irmandade de São Benedito no Convento de Santo Antônio da cidade do Recife, IAN/TT, Chancelarias Antigas - Ordem de Cristo, Livro 283, fls. 167-173.

${ }^{31}$ BNL. Anônimo, A Inclita Virgem Santa Ifigênia, Princesa do Reino da Núbia, Religiosa Carmelita.

${ }^{32}$ BNL. Santa Anna, José Pereira de. Segundo Atlante de Ethiopia Santa Ifigênia, Princeza do Reyno da Núbia; Religiosa Carmelita, Advogada contra os incêndios. Tomo Segundo.

${ }^{33}$ BNL. Anônimo, A Inclita Virgem Santa Ifigênia, Princesa do Reino da Núbia, Religiosa Carmelita, De cor Preta.

${ }^{34}$ BNL. Anônimo, A Inclita Virgem Santa Ifigênia, Princesa do Reino da Núbia, Religiosa Carmelita, De cor Preta.

${ }^{35}$ BNL. Anônimo, O Glorioso Santo Elesbão, Imperador da Etiopia Alta, Religioso Carmelita, Preto na Cor. Lisboa, século XVIII.

36 Arquivo da Ordem Terceira do Rosário das Portas do Carmo. Venerável Ordem Terceira do Rosário de Nossa Senhora às Portas do Carmo - Pelourinho, Irmandade de Homens Pretos, Devoção do Glorioso Santo Antônio de Categeró, s/d.

${ }^{37}$ Este autor utiliza como referência histórica principal a obra Vida y milagros del hermano Antônio de Catalagerona, santo negro de la Tercera Orden, colegida de tres processos autenticos y de noventa testigos jurados, escrita por Antônio Daça em 1610.

${ }^{38}$ Os estatutos da Irmandade de Santo Antônio de Catagerona foram submetidos à aprovação do Arcebispado da Bahia no ano de 1699. Consta no parecer do padre provisor uma reprimenda com respeito à imagem do santo pintada na capa do compromisso. Segundo o provisor e mestre escola Dom Sebastião dos Vale Pontes, era incorreta a representação do santo com o Cristo Menino nos braços "porque ainda que conste da sua vida ser muito devoto do santíssimo Nome de Jesus: não consta que este senhor em forma de menino lhe aparecesse, ou fizesse alguns favores, que é o que move a Igreja a permitir os Santos com o Menino Jesus nos braços", por este motivo, indicou em seu parecer "que até mais clara notícia, se pintem, e façam as Imagens deste santo (...) com uma cruz nas mãos, como se acha na casa dos $3^{\text {os. }}$ 
De São Francisco desta Cidade". Parecer do Padre Provisor Doutor Sebastião do Vale Pontes sobre o Compromisso da Irmandade de Santo Antonio de Categerona, cita na matriz de São Pedro na cidade da Bahia, 1699. Cardoso, "As irmandades na antiga Bahia". Revista Brasileira de História, pp. 251-52.

39 Carl Ruders. Viagem em Portugal, 1798-1802, Lisboa: Biblioteca Nacional, 1981, p.52.

40 Sobre o culto a Santo Antônio na África Central ver: John Thonrton. The Kongolese Saint Anthony, Dona Beatriz Kimpa Vita and the Antonian Movement, 1684-1706. Cambridge, Cambridge University Press, 1998.

${ }^{41}$ Testamento de José Manuel em 21 de dezembro de 1789, fls. 33v-34v. Agradeço a Roquinaldo Ferreira esta referência documental, IAN/TT, Feitos Findos - Justificações Ultramarinas, maço 16, doc. 9.

${ }^{42}$ Antonio de Oliveira Cadornega. História Geral das Guerras Angolanas [1680]. Lisboa, Agência Geral do Ultramar, 1972, p.27.

${ }^{43}$ AHU, Códice 21, fl. 8. Compromisso da Irmandade de São Benedito de Ribeirão do Carmo, Minas Gerais.

Artigo recebido em 03/2009. Aprovado em 06/2009 